\title{
Soil microbiological properties and available nitrogen for corn in monoculture and intercropped with forage
}

\author{
Thais Rodrigues Coser ${ }^{(1)}$, Maria Lucrécia Gerosa Ramos ${ }^{(1)}$, Cícero Célio de Figueiredo(1), \\ Arminda Moreira de Carvalho ${ }^{(2)}$, Eduardo Cavalcante ${ }^{(1)}$, Moacir Kildery dos Reis Moreira ${ }^{(3)}$, \\ Patrícia Silva Melo Araújo( ${ }^{(1)}$ and Sebastião Alberto de Oliveira(1)
}

\begin{abstract}
(1)Universidade de Brasília, Faculdade de Agronomia e Medicina Veterinária, Campus Universitário Darcy Ribeiro, Instituto Central de Ciências, Ala Sul, Caixa Postal 04508, CEP 70910-970 Brasília, DF, Brazil. E-mail: thacoser@gmail.com, lucrecia@unb.br, cicerocf@unb.br, eduardocavalcante@gmail.com, patriciasmaraujo@hotmail.com, saoliveira1949@gmail.com ${ }^{(2)}$ Embrapa Cerrados, BR 020, Km 18, Caixa Postal 08223, Planaltina, CEP 73310-970 Brasília, DF, Brazil. E-mail: arminda.carvalho@embrapa.br ${ }^{(3)} / n$ memoriam.
\end{abstract}

\begin{abstract}
The objective of this work was to evaluate the effects of corn (Zea mays) in monoculture and intercropped with forage on soil microbiological properties and nitrogen availability under no-tillage in the Cerrado (Brazilian savanna). The experiment was carried out from the 2007/2008 to the 2010/2011 crop season, in a Latossolo Vermelho-Amarelo distrófico (Typic Haplustox). A randomized complete block design with three replicates was used, with the following treatments: corn in monoculture; corn intercropped with Panicum maximum; corn intercropped with Urochloa humidicola; P. maximum in monoculture; and U. humidicola in monoculture. Soil samples were taken at $0.00-0.05,0.05-0.10,0.10-0.20$, and $0.20-0.30-\mathrm{m}$ soil depths, in the begining and in the end of the last crop season. The intercropping systems of corn increased soil nitrogen availability, but did not alter total nitrogen and organic carbon contents in the soil, when compared to corn in monoculture. Corn intercropped with P. maximum increased soil microbial biomass nitrogen and microbial nitrogen quotient, in comparison to corn in monoculture, as well soil as microbial biomass carbon in the surface soil layer, when compared to corn intercropped with $U$. humidicola.
\end{abstract}

Index terms: Panicum maximum, Urochloa humidicola, Zea mays, nitrogen microbial quotient, soil microbial biomass, soil quality.

\section{Propriedades microbiológicas do solo e disponibilidade de nitrogênio para milho em monocultura e em consórcio com forrageiras}

Resumo - O objetivo deste trabalho foi avaliar o efeito de cultivos de milho (Zea mays) em monocultura e consorciado com forrageiras nas propriedades microbiológicas de solo e na disponibilidade de nitrogênio, em plantio direto, no Cerrado. O experimento foi realizado nas safras de 2007/2008 até 2010/2011, em Latossolo Vermelho-Amarelo distrófico. Utilizou-se o delineamento de blocos ao acaso, com três repetições e os seguintes tratamentos: milho em monocultura; milho em consórcio com Panicum maximum; milho em consórcio com Urochloa humidicola; P. maximum em monocultura; e U. humidicola em monocultura. Amostras de solos foram retiradas nas profundidades de $0,00-0,05,0,05-0,10,0,10-0,20$ e $0,20-0,30 \mathrm{~m}$, no início e no final da última safra. Os cultivos consorciados de milho aumentaram o nitrogênio disponível no solo, mas não alteraram os conteúdos totais de nitrogênio e carbono orgânico, quando comparado ao cultivo do milho em monocultura. O consórcio de milho com P. maximum aumentou o nitrogênio da biomassa microbiana e o quociente microbiano de nitrogênio no solo, em comparação ao milho em monocultura, bem como o carbono da biomassa microbiana, na camada superficial do solo, quando comparado ao consórcio com U. humidicola.

Termos para indexação: Panicum maximum, Urochloa humidicola, Zea mays, quociente microbiano de nitrogênio, biomassa microbiana do solo, qualidade do solo.

\section{Introduction}

The adoption of no-tillage (NT) practices when intercropping forages with cash crops has great potential to improve soil quality through carbon sequestration, water and nutrient cycling, and improvement of soil biological diversity (Lemaire et al., 2014). The Cerrado (Brazilian savanna) biome is occupied with approximately $26 \%$ of pasture lands, with several degrees of degradation (Sano et al., 2010), and accounts for $45 \%$ of corn production in the Midwest region of Brazil (Acompanhamento..., 2015). Therefore, the use of diversified systems in the Cerrado, such as cash crop-forage intercropping, should be encouraged and better understood. 
Soil organic matter (SOM) is considered a key indicator of soil quality because it is the most important component of soil fertility in highly weathered soils (Lopes et al., 2013). Studies have reported increases in SOM under NT practices with intercropping of forages and cash crops, mainly due to higher inputs of plant residues, which can increase soil nutrient availability and soil $\mathrm{C}$ sequestration (Boeni et al., 2014). Increments in soil organic $C$ are commonly related to improvements in chemical and biological properties (Araújo et al., 2007; Lopes et al., 2013).

Increases in soil microbial biomass (SMB), under NT, are well documented (Figueiredo et al., 2007; Ferreira et al., 2011). However, differences in plant residue quality and chemical composition may affect SMB growth (Ferreira et al., 2011; Cong et al., 2015), which, in turn, may be positively related to $\mathrm{N}\left(\mathrm{NO}_{3}{ }^{-}\right.$ and $\mathrm{NH}_{4}^{+}$) mineralization potential in the soil and, consequently, to its uptake by SMB (Burger \& Jackson, 2003). Dourado-Neto et al. (2010) highlighted that, in tropical agroecosystems, soil $\mathrm{N}$ pool can provide up to $79 \%$ of the total $\mathrm{N}$ uptake by plants, showing the importance of SOM preservation and of plant residue inputs for $\mathrm{N}$ availability to crops.

To reduce environmental impacts on the Cerrado, one of the most threatened biomes in the world (Hunke et al., 2015), intercropping systems have been increasingly adopted. However, there is still a lack of information on the effects of different combinations of plant species on soil microbiota and on $\mathrm{N}$ availability in these systems for the Cerrado. Plant species differ in the way they allocate biomass and, therefore, in the quantity and quality of their residues (Carvalho et al., 2012), which may affect $C$ input and the levels of $N$ and microbial biomass in the soil.

The objective of this work was to evaluate the effects of corn (Zea mays L.) in monoculture and intercropped with forage on soil microbiological properties and $\mathrm{N}$ availability under no-tillage in the Cerrado (Brazilian savanna).

\section{Materials and Methods}

The experiment was conducted at the experimental farm of Universidade de Brasília, DF, Brazil (155' 'S, $47^{\circ} 51^{\prime} \mathrm{W}$, at 1,080-m altitude). The climate, according to Köppen, is Aw, a seasonal tropical savanna, and the soil of the studied area is classified as a Latossolo
Vermelho-Amarelo distrófico, i.e., a Typic Haplustox. Prior to the experiment, in 2007, the following results were obtained from soil chemical and particle analyses, in the $0.0-0.20-\mathrm{m}$ layer: $5.6 \mathrm{pH}$ in water; $0.5 \mathrm{mg} \mathrm{dm}^{-3} \mathrm{P}$ (Mehlich-1); $19.6 \mathrm{mg} \mathrm{dm}^{-3} \mathrm{~K}^{+} ; 0.9 \mathrm{cmol}_{\mathrm{c}} \mathrm{dm}^{-3} \mathrm{Ca}^{2+} ; 0.6$ $\mathrm{cmol}_{\mathrm{c}} \mathrm{dm}^{-3} \mathrm{Mg}^{2+} ; 4.6 \mathrm{cmol}_{\mathrm{c}} \mathrm{dm}^{-3} \mathrm{H}+\mathrm{Al} ; 0.2 \mathrm{cmol}_{\mathrm{c}} \mathrm{dm}^{-3}$ $\mathrm{Al}^{3+} ; 32.5 \mathrm{~g} \mathrm{dm}^{-3}$ organic matter; $525 \mathrm{~g} \mathrm{~kg}^{-1}$ clay; 275 $\mathrm{g} \mathrm{kg}^{-1}$ silt; and $200 \mathrm{~g} \mathrm{~kg}^{-1}$ sand.

Fifteen experimental plots were established in October 2007, in an area where Andropogon gayanus Kunth 'Planaltina' had been grown for a period of six years. Each plot had $80 \mathrm{~m}^{2}(10 \times 8 \mathrm{~m})$, of which 48 $\mathrm{m}^{2}$ were evaluated. The experiment consisted of the following treatments under NT: corn in monoculture; corn intercropped with Panicum maximum Jacq. 'Aruana'; corn intercropped with Urochloa humidicola (Rendle) Morrone \& Zuloaga; P. maximum in monoculture; and $U$. humidicola in monoculture. A randomized complete block design, with three replicates, was used. The experimental plots were kept as previously described, and agricultural practices were repeated in the following cash crop seasons: 2007/2008, 2008/2009, 2009/2010, and 2010/2011.

In November 2010, prior to corn sowing, a herbicide mixture of glyphosate [N-(phosphonomethyl) glycine], with $1.08 \mathrm{~kg} \mathrm{ha}^{-1}$ a.i. (3 $\left.\mathrm{L} \mathrm{ha}^{-1}\right)$, and of 2.4-dichlorophenoxyacetic acid (2.4-D), with $1.1 \mathrm{~kg} \mathrm{ha}^{-1}$ a.i. $\left(1.5 \mathrm{~L} \mathrm{ha}^{-1}\right)$, was applied for forage and weed desiccation.

The early-maturing triple-cross corn hybrid 'BG7055' was sown in December 2010, in eight rows spaced $0.9 \mathrm{~m}$ apart, with six plants per meter, totaling 65,000 plants per hectare. For fertilization, $30 \mathrm{~kg} \mathrm{ha}^{-1} \mathrm{~N}, 100 \mathrm{~kg} \mathrm{ha}^{-1} \mathrm{P}_{2} \mathrm{O}_{5}, 70 \mathrm{~kg} \mathrm{ha}^{-1} \mathrm{~K}_{2} \mathrm{O}$, and $66 \mathrm{~kg} \mathrm{ha}^{-1}$ fritted trace elements (FTE) BR-12 were applied. Forty-four days after corn emergence, when plants had around eight leaves, $70 \mathrm{~kg} \mathrm{ha}^{-1} \mathrm{~N}$ were also applied in the form of ammonium sulfate.

The species $P$. maximum and $U$. humidicola were sown in the 2007/2008 and 2009/2010 seasons with $30 \mathrm{~kg} \mathrm{ha}^{-1}$ seed, considering the pure live seed percentage. The same procedure was adopted in the intercropping and monoculture plots. The seeds were sown in between corn rows, after corn seeding. The average amount of plant biomass (dry matter) produced by the $P$. maximum and $U$. humidicola forages in consortium, at the end of the 2009/2010 season, was 2.17 and $2.12 \mathrm{Mg} \mathrm{ha}^{-1}$, respectively. In the

Pesq. agropec. bras., Brasília, v.51, n.9, p.1660-1667, set. 2016 DOI: 10.1590/S0100-204X2016000900066 
plots with monoculture forages, the obtained values were $1.74 \mathrm{Mg} \mathrm{ha}^{-1}$ for P. maximum and $2.10 \mathrm{Mg} \mathrm{ha}^{-1}$ for $U$. humidicola. The plots with monoculture forage received $60 \mathrm{~kg} \mathrm{ha}^{-1} \mathrm{P}_{2} \mathrm{O}_{5}$ and $60 \mathrm{~kg} \mathrm{ha}^{-1} \mathrm{~K}_{2} \mathrm{O}$, and $\mathrm{N}$ was divided into two side-dressing doses of $30 \mathrm{~kg} \mathrm{ha}^{-1}$, totaling $60 \mathrm{~kg} \mathrm{ha}^{-1} \mathrm{~N}$.

Soil samples were collected at the beginning (before corn planting) and at the end (after harvest) of the 2010/2011 crop season, in December 2010 and April 2011, respectively, at the depths of: $0.00-0.05,0.05-$ $0.10,0.10-0.20$, and $0.20-0.30 \mathrm{~m}$. For each plot, 15 subsamples were collected at three locations within the plot. At each location, one sample was collected in the planting row and another four samples were collected in between corn rows (equidistant lines).

Total organic carbon (TOC) was determined by oxidation with potassium dichromate in the presence of acid without external heat source (Walkley \& Black, 1934). Total soil nitrogen (TN) was estimated by the Kjeldahl method, according to Bremner \& Mulvaney (1982).

To measure available $\mathrm{N}$, the extraction method $\mathrm{Na}_{3} \mathrm{PO}_{4}$ /borax buffer $\mathrm{pH} 11.2+\mathrm{NO}_{3}{ }^{-}$was used (Serra, 2006). Calculations were performed from the calibration curve obtained with the distillation of standard solutions containing $0,15,30,45$, and $60 \mu \mathrm{g} \mathrm{mL}^{-1} \mathrm{~N}$. The extracted $\mathrm{N}$ was determined by colorimetric spectrophotometry at $440 \mathrm{~nm}$.

Microbial biomass nitrogen (MBN) was obtained with the method of chloroform fumigation-extraction, described by Brookes et al. (1985) and Vance et al. (1987), using a correction factor of 0.54 (Wardle, 1994), and the microbial nitrogen quotient (qMIN) was determined by the ratio between MBN and TN. In addition, microbial biomass carbon (MBC) was calculated according to Vance et al. (1987), using a correction factor of 0.38 (Wardle, 1994), whereas the microbial carbon quotient (qMIC) was obtained by the ratio between MBC and TOC.

Data were subjected to the analysis of variance, and the means were compared by Tukey's studentized range test, at 5\% probability. Data from all treatments, depths, and sampling periods were further analyzed with Pearson's linear correlation analysis. Analyses were performed using the Sisvar software, version 5.3 (Universidade Federal de Lavras, Lavras, MG, Brazil).

\section{Results and Discussions}

The corn/U. humidicola intercropping provided the highest contents of TOC and TN in the $0.00-0.05-\mathrm{m}$ soil layer, whereas $U$. humidicola in monoculture, the lowest ones (Figure 1). These results indicate the benefits of integrating this forage with corn, with increases of $13 \%$ in TOC and $9 \%$ in TN in the uppermost soil layer, when compared to sole $U$. humidicola. Corn fertilization may have increased forage root development - which, in some species, can reach up to $4 \mathrm{Mg} \mathrm{ha}^{-1}$ in the $0.00-0.40-\mathrm{m}$ layer (Saraiva et al., 2014) - and affected soil TOC and TN. Moreover, under NT systems, corn roots, which are more concentrated in surface soil layers (Silva et al., 2000), together with the deposition of plant residues, may have also contributed to increases in TOC and TN. It should be noted, that although the enhanced levels of $\mathrm{TN}$ may also be attributed to $\mathrm{N}$ fertilization in corn, the simultaneous increase in TOC suggests the possibility of synergy between $\mathrm{C}$ and $\mathrm{N}$, whereby $\mathrm{C}$ sequestration enhances $\mathrm{N}$ sequestration, and vice versa (Cong et al., 2015). Diógenes et al. (2013) found higher TOC values for corn intercropped with $U$.ruziziensis, when compared to this forage in monoculture.

Four years after the establishment of the experiment, no differences were found in TOC content between $U$. humidicola and $P$. maximum, nor between the intercropping systems and corn in monoculture. The largest compartment of organic $\mathrm{C}$, approximately $67 \%$, in Oxisols in the Cerrado region is allocated in organomineral complexes, an interaction that minimizes microbial attack and decomposition, reducing the turnover rate of organic matter (Boemi et al., 2014). This may explain the lack of significant differences between some of the management systems. Changes in $\mathrm{C}$ concentration from particulate organic matter, which accounts for $33 \%$ of TOC and plays a very important role in biological activity, are more evident following shifts in soil management and cropping systems (Coser et al., 2012; Boeni et al., 2014).

The corn/P. maximum intercropping system showed the highest soil $\mathrm{N}$ availability (AN) in the $0.00-0.05-\mathrm{m}$ layer and prior to corn planting, followed by corn $/ U$. humidicola, P. maximum, corn, and U. humidicola (Table 1). Corn/P. maximum also increases $\mathrm{C}$ content of the particulate organic matter fraction, indicating that this may be the reason for higher AN under this system (Burger \& Jackson, 2003; Coser et al., 2012). 


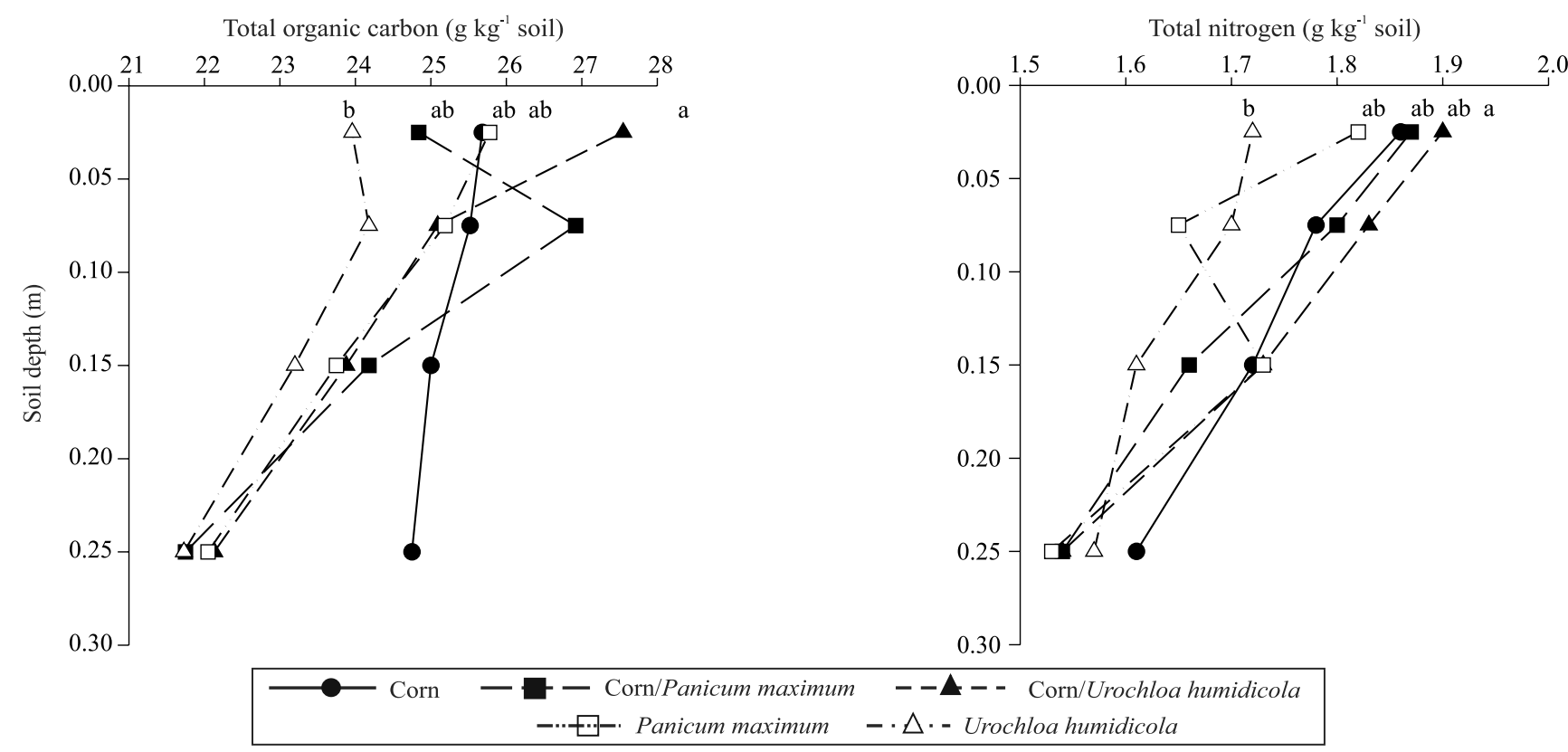

Figure 1. Total organic carbon and nitrogen in soil under monoculture of corn (Zea mays), Panicum maximum, and Urochloa humidicola, as well as under integrated systems with these species, at different soil depths. Means followed by equal letters do not differ by Tukey's test, at $5 \%$ probability.

Table 1. Available nitrogen and its relation to total nitrogen in soil under monoculture of corn (Zea mays), Panicum maximum, and Urochloa humidicola, as well as under integrated systems with these species, at different soil depths, in two sampling periods: before planting of corn and after corn harvest ${ }^{(1)}$.

\begin{tabular}{|c|c|c|c|c|}
\hline \multirow[t]{2}{*}{ Cropping system } & \multicolumn{2}{|c|}{ Available nitrogen $\left(\mathrm{mg} \mathrm{kg}^{-1}\right)$} & \multicolumn{2}{|c|}{ Available nitrogen/ Total nitrogen (\%) } \\
\hline & Before planting corn & After corn harvest & Before planting corn & After corn harvest \\
\hline & \multicolumn{4}{|c|}{$0.0-0.05 \mathrm{~m}$} \\
\hline Corn & $50.42 \mathrm{bA}$ & $54.10 \mathrm{aA}$ & $2.87 \mathrm{aA}$ & $2.80 \mathrm{aA}$ \\
\hline Corn/Panicum maximum & $71.12 \mathrm{aA}$ & $53.33 \mathrm{aB}$ & $3.78 \mathrm{aA}$ & $2.89 \mathrm{aB}$ \\
\hline Corn/Urochloa humidicola & $68.93 \mathrm{aA}$ & $53.42 \mathrm{aB}$ & $3.84 \mathrm{aA}$ & $2.69 \mathrm{aB}$ \\
\hline Panicum maximum & $67.54 \mathrm{aA}$ & $59.21 \mathrm{aA}$ & $3.72 \mathrm{aA}$ & $3.24 \mathrm{aA}$ \\
\hline \multirow[t]{2}{*}{$\underline{\text { Urochloa humidicola }}$} & $48.76 \mathrm{bA}$ & $59.42 \mathrm{aA}$ & $2.82 \mathrm{aA}$ & $3.50 \mathrm{aA}$ \\
\hline & \multicolumn{4}{|c|}{$0.05-0.10 \mathrm{~m}$} \\
\hline Corn & & & & \\
\hline Corn/Panicum maximum & & & & \\
\hline Corn/Urochloa humidicola & & & & \\
\hline Panicum maximum & & & & \\
\hline Urochloa humidicola & & & & \\
\hline \multirow[t]{2}{*}{ Sampling periods } & $59.24 \mathrm{~A}$ & $52.70 \mathrm{~B}$ & $3.37 \mathrm{~A}$ & $3.05 \mathrm{~A}$ \\
\hline & \multicolumn{4}{|c|}{$0.10-0.20 \mathrm{~m}$} \\
\hline Corn & & & & \\
\hline Corn/Panicum maximum & & & & \\
\hline Corn/Urochloa humidicola & & & & \\
\hline Panicum maximum & & & & \\
\hline Urochloa humidicola & & & & \\
\hline \multirow[t]{2}{*}{ Sampling periods } & $55.06 \mathrm{~A}$ & $54.21 \mathrm{~A}$ & $3.25 \mathrm{~A}$ & $3.23 \mathrm{~A}$ \\
\hline & \multicolumn{4}{|c|}{$0.20-0.30 \mathrm{~m}$} \\
\hline Corn & & & & \\
\hline Corn/Panicum maximum & & & & \\
\hline Corn/Urochloa humidicola & & & & \\
\hline Panicum maximum & & & & \\
\hline Urochloa humidicola & & & & \\
\hline Sampling periods & $49.43 \mathrm{~A}$ & $46.83 \mathrm{~A}$ & $3.30 \mathrm{~A}$ & $2.91 \mathrm{~B}$ \\
\hline
\end{tabular}

\footnotetext{
${ }^{(1)}$ Means followed by equal letters, uppercase in the rows and lowercase in the columns, do not differ by Tukey's test, at $5 \%$ probability.
} 
Furthermore, $78 \%$ of the mineralizable $\mathrm{N}$ in the soil depends on the size and fraction proportions of SOM (Ros et al., 2011).

The content of available $\mathrm{N}$ under the intercropping systems decreased from the beginning to the end of the season, possibly indicating net $\mathrm{N}$ mineralization of $\mathrm{N}$-organic forms during the rainy season or uptake of $\mathrm{N}$ $\left(\mathrm{NO}_{3}{ }^{-}-\mathrm{N}\right.$ and $\left.\mathrm{NH}_{4}{ }^{+}-\mathrm{N}\right)$ by the plants during this period.

Considering all the cropping systems, depths, and sampling periods, the percentage of AN compared to $\mathrm{TN}(\mathrm{AN} / \mathrm{TN})$ ranged from 2.75 to $3.94 \%$, with no significant differences (Table 1). These ranges indicate that only a small fraction of $\mathrm{TN}$ is easily decomposable by soil microorganisms.

MBN ranged from 10.47 to $48.31 \mathrm{mg} \mathrm{kg}^{-1}$, which represented between 0.67 and $2.79 \%$ of TN (Table 2). Corn/ $P$. maximum showed the highest soil MBN in the $0.00-0.05-\mathrm{m}$ layer, prior to corn sowing, which was significantly higher than that of the sole cropping systems (Table 2). The species $U$. humidicola and $P$. maximum in monocultures did not differ from each other regarding MBN and qMIN, in the $0.00-0.05 \mathrm{~m}$ layer. The introduction of $P$. maximum as an intercrop in corn production systems favors SMB growth in this soil layer. Higher qMIN and MBN in the corn $/ P$. maximum intercropping system may represent higher $\mathrm{N}$ cycling efficiency and availability in short-term periods (Xavier et al., 2006).

After corn harvest, corn/U. humidicola showed higher MBN and qMIN in the $0.00-0.05-\mathrm{m}$ layer than corn in monoculture. This may be explained by root exudates released by $U$. humidicola, which inhibit soil nitrification (Subbarao et al., 2006) and may reduce $\mathrm{N}$ losses in the form of $\mathrm{NO}_{3}^{-}-\mathrm{N}$, increasing soil microbial biomass $\mathrm{N}$. The soil nitrification process under $P$. maximum was between $47-73 \%$ lower than under $U$. humidicola (Ipinmoroti et al., 2008).

Table 2. Microbial biomass nitrogen and microbial nitrogen quotient (qMIN) in soil under monoculture of corn (Zea mays), Panicum maximum, and Urochloa humidicola, as well as under integrated systems with these species, at different soil depths, in two sampling periods: before planting of corn and after corn harvest ${ }^{(1)}$.

\begin{tabular}{|c|c|c|c|c|}
\hline \multirow[t]{2}{*}{ Cropping system } & \multicolumn{2}{|c|}{ Microbial biomass nitrogen $\left(\mathrm{mg} \mathrm{kg}^{-1}\right)$} & \multicolumn{2}{|c|}{ qMIN (\%) } \\
\hline & Before planting corn & After corn harvest & Before planting corn & After corn harvest \\
\hline & \multicolumn{4}{|c|}{$0.00-0.05 \mathrm{~m}$} \\
\hline Corn & \multicolumn{2}{|c|}{$27.71 b$} & \multicolumn{2}{|c|}{$1.51 \mathrm{~b}$} \\
\hline Corn/Panicum maximum & \multicolumn{2}{|c|}{$48.31 \mathrm{a}$} & \multicolumn{2}{|c|}{$2.59 \mathrm{a}$} \\
\hline Corn/Urochloa humidicola & \multicolumn{2}{|c|}{$34.99 \mathrm{ab}$} & \multicolumn{2}{|c|}{$1.88 \mathrm{ab}$} \\
\hline Panicum maximum & \multicolumn{2}{|c|}{$27.96 b$} & \multicolumn{2}{|c|}{$1.54 \mathrm{~b}$} \\
\hline Urochloa humidicola & \multicolumn{2}{|c|}{$33.97 \mathrm{~b}$} & \multicolumn{2}{|c|}{$1.98 \mathrm{ab}$} \\
\hline \multirow[t]{2}{*}{ Sampling period } & $36.31 \mathrm{~A}$ & $32.87 \mathrm{~B}$ & $2.02 \mathrm{~A}$ & $1.77 \mathrm{~B}$ \\
\hline & \multicolumn{4}{|c|}{$0.05-0.10 \mathrm{~m}$} \\
\hline Corn & $28.90 \mathrm{abA}$ & $25.63 \mathrm{bA}$ & $1.56 \mathrm{abA}$ & $1.49 \mathrm{bA}$ \\
\hline Corn/Panicum maximum & $20.69 \mathrm{bB}$ & $33.26 \mathrm{abA}$ & $1.16 \mathrm{bB}$ & $1.85 \mathrm{bA}$ \\
\hline Corn/Urochloa humidicola & $38.79 \mathrm{aA}$ & $41.30 \mathrm{aA}$ & $2.22 \mathrm{aA}$ & $2.15 \mathrm{abA}$ \\
\hline Panicum maximum & $25.08 \mathrm{abB}$ & $36.39 \mathrm{abA}$ & $1.49 \mathrm{abB}$ & $2.27 \mathrm{aA}$ \\
\hline \multirow[t]{2}{*}{ Urochloa humidicola } & $24.54 \mathrm{bB}$ & $45.19 \mathrm{aA}$ & $1.42 \mathrm{bB}$ & $2.71 \mathrm{aA}$ \\
\hline & \multicolumn{4}{|c|}{$0.10-0.20 \mathrm{~m}$} \\
\hline Corn & $14.57 \mathrm{bB}$ & $30.77 \mathrm{aA}$ & $0.82 \mathrm{bB}$ & $1.87 \mathrm{aA}$ \\
\hline Corn/Panicum maximum & $29.46 \mathrm{abB}$ & $45.17 \mathrm{aA}$ & $1.73 \mathrm{abB}$ & $2.79 \mathrm{aA}$ \\
\hline Corn/Urochloa humidicola & $20.47 \mathrm{bB}$ & $45.97 \mathrm{aA}$ & $1.23 \mathrm{abB}$ & $2.57 \mathrm{aA}$ \\
\hline Panicum maximum & $42.29 \mathrm{aA}$ & $31.54 \mathrm{aA}$ & $2.50 \mathrm{aA}$ & $1.85 \mathrm{aA}$ \\
\hline \multirow[t]{2}{*}{ Urochloa humidicola } & $12.50 \mathrm{bB}$ & $33.46 \mathrm{aA}$ & $0.79 \mathrm{bB}$ & $2.06 \mathrm{aA}$ \\
\hline & \multicolumn{4}{|c|}{$0.20-0.30 \mathrm{~m}$} \\
\hline Corn & $21.47 \mathrm{aB}$ & $30.70 \mathrm{bA}$ & $1.40 \mathrm{aB}$ & $1.84 \mathrm{bA}$ \\
\hline Corn/Panicum maximum & $20.93 \mathrm{aB}$ & $27.31 \mathrm{bA}$ & $1.39 \mathrm{aA}$ & $1.74 \mathrm{bA}$ \\
\hline Corn/Urochloa humidicola & $26.05 \mathrm{aA}$ & $24.81 \mathrm{bA}$ & $1.85 \mathrm{aA}$ & $1.50 \mathrm{bA}$ \\
\hline Panicum maximum & $21.18 \mathrm{aB}$ & $27.84 \mathrm{bA}$ & $1.44 \mathrm{aA}$ & $1.75 \mathrm{bA}$ \\
\hline Urochloa humidicola & $10.47 \mathrm{bB}$ & $40.56 \mathrm{aA}$ & $0.67 \mathrm{bB}$ & $2.58 \mathrm{aA}$ \\
\hline
\end{tabular}

${ }^{(1)}$ Means followed by equal letters, uppercase in the rows and lowercase in the columns, do not differ by Tukey's test, at $5 \%$ probability. 
Comparing the tropical forages, $\mathrm{MBN}$ and qMIN were higher under $P$. maximum in the $0.10-0.20$ and $0.20-0.30-\mathrm{m}$ soil layers, prior to corn planting. However, after corn harvest, U. humidicola showed greater MBN and qMIN than $P$. maximum, possibly due to the nitrification inhibitors released by this forage.

MBC ranged from 74.73 to $248.9 \mathrm{mg} \mathrm{kg}^{-1}$ (Table 3). Considering the interpretative classes for microbial indicators in a clayey Oxisol in the Cerrado region (Lopes et al., 2013), the MBC values in the 0.00-0.05 and $0.05-0.10-\mathrm{m}$ layers varied from low to moderate.

The amount of MBC obtained under corn $/ P$. maximum (248.9 mg kg-1 soil) was almost twice as

Table 3. Microbial biomass carbon (MBC) and microbial carbon quotient (qMIC) in soil under monoculture of corn (Zea mays), Panicum maximum, and Urochloa humidicola, as well as under integrated systems with these species, at different soil depths, in two sampling periods: before planting of corn (BPC) and after corn harvest (ACH) ${ }^{(1)}$.

\begin{tabular}{|c|c|c|c|c|}
\hline \multirow[t]{2}{*}{ Cropping system } & \multicolumn{2}{|c|}{$\mathrm{MBC}\left(\mathrm{mg} \mathrm{kg}^{-1}\right)$} & \multicolumn{2}{|c|}{ qMIC (\%) } \\
\hline & $\mathrm{BPC}$ & $\mathrm{ACH}$ & $\mathrm{BPC}$ & $\mathrm{ACH}$ \\
\hline & \multicolumn{4}{|c|}{$0.00-0.05 \mathrm{~m}$} \\
\hline Corn & \multicolumn{2}{|c|}{$193.2 \mathrm{ab}$} & \multicolumn{2}{|c|}{$0.75 \mathrm{ab}$} \\
\hline Corn/Panicum maximum & \multicolumn{2}{|c|}{$248.9 \mathrm{a}$} & \multicolumn{2}{|c|}{$1.03 \mathrm{a}$} \\
\hline Corn/Urochloa humidicola & \multicolumn{2}{|c|}{$127.2 \mathrm{~b}$} & \multicolumn{2}{|c|}{$0.45 b$} \\
\hline Panicum maximum & \multicolumn{2}{|c|}{$210.7 \mathrm{ab}$} & \multicolumn{2}{|c|}{$0.84 a b$} \\
\hline Urochloa humidicola & \multicolumn{2}{|c|}{$149.3 \mathrm{~b}$} & \multicolumn{2}{|c|}{$0.64 \mathrm{ab}$} \\
\hline \multirow[t]{2}{*}{ Sampling period } & $172.0 \mathrm{~A}$ & $199.7 \mathrm{~A}$ & $0.73 \mathrm{~A}$ & $0.76 \mathrm{~A}$ \\
\hline & \multicolumn{4}{|c|}{$0.05-0.10 \mathrm{~m}$} \\
\hline Corn & \multicolumn{2}{|c|}{$167.4 \mathrm{ab}$} & \multicolumn{2}{|c|}{$0.65 a b$} \\
\hline Corn/Panicum maximum & \multicolumn{2}{|c|}{$173.7 \mathrm{ab}$} & \multicolumn{2}{|c|}{$0.66 \mathrm{ab}$} \\
\hline Corn/Urochloa humidicola & \multicolumn{2}{|c|}{$202.2 \mathrm{a}$} & \multicolumn{2}{|c|}{$0.82 \mathrm{a}$} \\
\hline Panicum maximum & \multicolumn{2}{|c|}{$126.8 \mathrm{~b}$} & \multicolumn{2}{|c|}{$0.51 \mathrm{~b}$} \\
\hline Urochloa humidicola & \multicolumn{2}{|c|}{$141.1 \mathrm{ab}$} & \multicolumn{2}{|c|}{$0.60 \mathrm{ab}$} \\
\hline \multirow[t]{2}{*}{ Sampling period } & $138.3 \mathrm{~B}$ & $186.1 \mathrm{~A}$ & $0.57 \mathrm{~A}$ & $0.72 \mathrm{~A}$ \\
\hline & \multicolumn{4}{|c|}{$0.10-0.20 \mathrm{~m}$} \\
\hline Corn & \multicolumn{2}{|c|}{$151.3 \mathrm{ab}$} & \multicolumn{2}{|c|}{$0.61 \mathrm{ab}$} \\
\hline Corn/Panicum maximum & \multicolumn{2}{|c|}{$187.0 \mathrm{a}$} & \multicolumn{2}{|c|}{$0.78 \mathrm{a}$} \\
\hline Corn/Urochloa humidicola & 122 & & & \\
\hline Panicum maximum & 159 & & & \\
\hline Urochloa humidicola & & $34 \mathrm{c}$ & & \\
\hline Sampling period & $127.3 \mathrm{~B}$ & $154.6 \mathrm{~A}$ & $0.58 \mathrm{~A}$ & $0.62 \mathrm{~A}$ \\
\hline & & 0.20 & $30 \mathrm{~m}$ & \\
\hline Corn & 180 & & & \\
\hline Corn/Panicum maximum & & $73 b$ & & \\
\hline Corn/Urochloa humidicola & 107 & & & \\
\hline Panicum maximum & 130 & & & \\
\hline Urochloa humidicola & 150 & & & \\
\hline Sampling period & $119.6 \mathrm{~A}$ & $137.8 \mathrm{~A}$ & $0.60 \mathrm{~A}$ & $0.58 \mathrm{~A}$ \\
\hline
\end{tabular}

high as with corn/U. humidicola (127.2 $\mathrm{mg} \mathrm{kg}^{-1}$ soil). Since both forages produced similar amounts of shoot dry matter in the 2009/2010 season (2.12 and 2.17 $\mathrm{Mg} \mathrm{ha}^{-1}$, respectively), the higher MBC under corn/ $P$. maximum may be related to the quality of its residues, including lower $\mathrm{C}: \mathrm{N}$ ratios and lignin contents. Plant litter quality can explain decomposition rates and the release of nutrients to the soil, affecting the levels of MBC (Carvalho et al., 2012).

When both forages were compared as a monoculture, $P$. maximum had higher $\mathrm{MBC}$ in the $0.10-0.20-\mathrm{m}$ layer. Lopes et al. (2010) reported that MBC is greater under $P$. maximum pastures than in those with Urochloa spp., in the 0.00-0.10-m layer. These authors associated the higher content of MBC in P. maximum pastures with greater amounts of shoot dry matter and released exudates, when compared to Urochloa spp. However, in the present study, the amounts of shoot dry matter produced by both forages were similar and, therefore, the greatest MBC values should be related to root exudates and to the chemical composition of $P$. maximum litter.

Comparing sampling periods, $\mathrm{MBC}$ ranged from 119.6 to $172 \mathrm{mg} \mathrm{kg}^{-1}$, prior to corn planting, and from 137.8 to $199.7 \mathrm{mg} \mathrm{kg}^{-1}$ after corn harvest. However, differences between sampling periods were only significant between the layers at $0.05-0.20-\mathrm{m}$ soil depths, in which $\mathrm{MBC}$ was greater after corn harvest (Table 3). As also observed for TOC, higher MBC after corn harvest may be associated with the decomposition of plant residues and to nutrient mineralization, which would provide nutrients to SMB during the corn growing season.

The ratio of biomass $\mathrm{C}$ to soil organic $\mathrm{C}$ (qMIC) reflects the contribution of microbial biomass to soil organic $\mathrm{C}$ and, therefore, indicates the quality of SOM (Wardle, 1994). Differences in qMIC among cropping systems were found up to $0.20-\mathrm{m}$ depth (Table 3 ), with values ranging from 1.03 to $0.33 \%$. As also verified for $\mathrm{MBC}$, corn $P$. maximum showed greater qMIC than corn/ $U$. humidicola in the $0.00-0.05$ and $0.10-0.20-\mathrm{m}$ layers. Therefore, corn $/ P$. maximum seems to be more efficient in converting TOC in MBC than corn $/ U$. humidicola (Wardle, 1994).

Despite the similarity in the values of qMIN and AN/TN, the lack of correlation between AN and MBN may be an indication that the AN pool is a distinct fraction of MBN (Table 4). However, it is important

Pesq. agropec. bras., Brasília, v.51, n.9, p.1660-1667, set. 2016 DOI: 10.1590/S0100-204X2016000900066 
Table 4. Pearson's correlation coefficient between microbial biomass nitrogen (MBN), total nitrogen (TN), MBN/ TN (qMIN), available N (AN), microbial biomass carbon (MBC), total organic carbon (TOC), and $\mathrm{MBC} / \mathrm{TOC}$ (qMIC) in soil under monoculture of corn (Zea mays), Panicum maximum, and Urochloa humidicola, as well as under integrated systems with these species, at different soil depths.

\begin{tabular}{lcccccc}
\hline Variable & TN & qMIN & AN & MBC & TOC & qMIC \\
\hline MBN & $0.23^{* *}$ & $0.96^{* * *}$ & $0.08^{\text {ns }}$ & $0.39^{* * *}$ & $0.09^{\text {ns }}$ & $0.33^{* * *}$ \\
TN & - & $-0.02^{\text {ns }}$ & $0.27^{*}$ & $0.40^{* * *}$ & $0.45^{* * *}$ & $0.20^{*}$ \\
qMIN & & - & $0.01^{\text {ns }}$ & $0.29^{* *}$ & $-0.02^{\text {ns }}$ & $0.29^{* *}$ \\
AN & & & - & $0.20^{*}$ & $0.04^{\text {ns }}$ & $0.19^{*}$ \\
MBC & & & & - & $0.20^{*}$ & $0.90^{* * *}$ \\
TOC & & & & & - & $-0.21^{*}$ \\
qMIC & & & & & & - \\
\hline
\end{tabular}

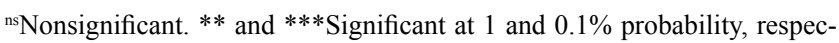
tively.

to outline that SMB may have mineralized AN during the corn growing season, as it decreased between sampling periods. Therefore, SMB was shown to be a source of N, rather than a sink. Significant correlations were observed between AN and TN. Yagi et al. (2009) reported that $\mathrm{TN}$ was the best indicator of soil $\mathrm{N}$ mineralization potential.

The results obtained in the present study, in a four year experiment, show that the effects of tropical forages intercropped with corn, under NT system, on soil $\mathrm{N}, \mathrm{C}$, and soil microbiological properties are mostly seen on the surface soil layer, where, in general, the presence of $P$. maximum represented an interesting alternative for intercropping, since it increases $\mathrm{N}$ and MBN availability in the soil. Increases in soil C, N, and microbial biomass may further benefit soil fertility and productivity of intercropping systems in the Brazilian Cerrado.

\section{Conclusions}

1. Intercropping systems of corn (Zea mays) with the evaluated tropical forages increase soil available nitrogen to the cash crop, microbial biomass carbon and nitrogen, and microbial nitrogen quotient, when compared to monocultures, especially in the $0.00-0.05-\mathrm{m}$ soil layer.

2. Panicum maximum provides greater stimulation of soil microbial biomass than Urochloa humidicola, which results in increased soil nitrogen availability.
3. The intercropping system with corn increases the capacity of $U$. humidicola to accumulate carbon and nitrogen in the $0.00-0.05-\mathrm{m}$ soil layer.

\section{Acknowledgments}

To Fundação de Apoio à Pesquisa do Distrito Federal (FAP-DF, process No. 2010/00435-9); and to Conselho Nacional de Desenvolvimento Científico e Tecnológico and to Ministério de Ciência e Tecnologia (CNPq/ MCT), for the fellowship of scientific productivity (No. 306983/2013-3) to the second author

\section{References}

ACOMPANHAMENTO DA SAFRA BRASILEIRA [DE] GRÃOS: safra 2014/2015: décimo levantamento. Brasília, v.2, n.10, jul. 2015. 109p.

ARAÚJO, R.; GOEDERT, W.J; LACERDA, M.P.C. Qualidade de um solo sob diferentes usos e sob Cerrado nativo. Revista Brasileira de Ciência do Solo, v.31, p.1099-1108, 2007. DOI: 10.1590/S0100-06832007000500025.

BOENI, M.; BAYER, C.; DIECKOW, J.; CONCEIÇÃO, P.C.; DICK, D.P.; KNICKER, H.; SALTON, J.C.; MACEDO, M.C.M. Organic matter composition in density fractions of Cerrado Ferralsols as revealed by CPMAS ${ }^{13} \mathrm{C}$ NMR: influence of pastureland, cropland and integrated crop-livestock. Agriculture, Ecosystems and Environment, v.190, p.80-86, 2014. DOI: 10.1016/j.agee.2013.09.024.

BREMNER, J.M.; MULVANEY, C.S. Nitrogen total. In: PAGE, A.L.; MILLER, R.H.; KEENEY, D.R. (Ed.). Methods of soil analysis: part 2: chemical and microbiological properties. $2^{\text {nd }} \mathrm{ed}$. Madison: American Society of Agronomy, 1982. p.595-624.

BROOKES, P.C.; LANDMAN, A.; PRUDEN, G.; JENKINSON, D.S. Chloroform fumigation and the release of soil nitrogen: a rapid direct extraction method to measure microbial biomass nitrogen in soil. Soil Biology and Biochemistry, v.17, p.837-842, 1985. DOI: 10.1016/0038-0717(85)90144-0.

BURGER, M.; JACKSON, L.E. Microbial immobilization of ammonium and nitrate in relation to ammonification and nitrification rates in organic and conventional cropping systems. Soil Biology and Biochemistry, v.35, p.29-36, 2003. DOI: 10.1016/S0038-0717(02)00233-X

CARVALHO, A.M. de; COELHO, M.C.; DANTAS, R.A.; FONSECA, O.P.; GUMARÃES JÚNIOR, R.; FIGUEIREDO, C.C. Chemical composition of cover plants and its effect on maize yield in no-tillage systems in the Brazilian savanna. Crop and Pasture Science, v.63, p.1075-1081, 2012. DOI: 10.1071/CP12272.

CONG, W.-F.; HOFFLAND, E.; LI, L.; JANSSEN, B.H.; WERF, W. van der. Intercropping affects the rate of decomposition of soil organic matter and root litter. Plant and Soil, v.391, p.399-411, 2015. DOI: $10.1007 / \mathrm{s} 11104-015-2433-5$. 
COSER, T.R.; FIGUEIREDO, C.C.; RAMOS, M.L.G.; JANNUZZI, H.; MARCHÃO, R.L. Recuperação de carbono obtida por três métodos em frações da matéria orgânica de Latossolo sob consórcio milho-forrageiras, no Cerrado. Bioscience Journal, v.28, p.91-97, 2012.

DIÓGENES, L.C.; NÓBREGA, J.C.A.; NÓBREGA, R.S.A.; ANDRADE JÚNIOR, A. de S.; PRAGANA, R.B.; MATIAS, S.S.R. Microbial attributes and carbon and nitrogen stocks in Latosol under irrigated monocropping and intercropping. Revista de Ciências Agrárias, v.56, p.106-111, 2013. DOI: 10.4322/ rca.2013.017.

DOURADO-NETO, D.; POWLSON, D.; ABU BAKAR, R.; BACCHI, O.O.S.; BASANTA, M.V.; CONG, P.T.; KEERTHISINGHE, G.; ISMAILI, M.; RAHMAN, S.M.; REICHARDT, K.; SAFWATI, M.S.A.; SANGAKKARA, R.; TIMM, L.C.; WANG, J.Y.; ZAGAL, E.; VAN KESSEL, C. Multiseason recoveries of organic and inorganic nitrogen-15 in tropical cropping systems. Soil Science Society American Journal, v.74, p.139-152, 2010. DOI: 10.2136/sssaj2009.0192.

FERREIRA, E.P. de B.; WENDLAND, E.A.; DIDONET, A.D. Microbial biomass and enzyme activity of a Cerrado Oxisol under agroecological production system. Bragantia, v.70, p.899-907, 2011. DOI: $10.1590 /$ S0006-87052011000400024.

FIGUEIREDO, C.C.; RESCK, D.V.S.; GOMES, A.C.; FERREIRA, E.A.B.; RAMOS, M.L.G. Carbono e nitrogênio da biomassa microbiana em resposta a diferentes sistemas de manejo em um Latossolo Vermelho no Cerrado. Revista Brasileira de Ciência do Solo, v.31, p.551-562, 2007. DOI: 10.1590/S010006832007000300015.

HUNKE, P.; MUELLER, E.N.; SCHRÖDER, B.; ZEILHOFER, P. The Brazilian Cerrado: assessment of water and soil degradation in catchments under intensive agricultural use. Ecohydrology, v.8, p.1154-1180, 2015. DOI: 10.1002/eco.1573.

IPINMOROTI, R.R.; WATANABE, T.; ITO, O. Effect of Brachiaria humidicola root exudates, rhizosphere soils, moisture and temperature regimes on nitrification inhibition in two volcanic ash soils of Japan. World Journal of Agricultural Science, v.4, p.106-113, 2008.

LEMAIRE, G.; FRANZLUEBBERS, A.; CARVALHO, P.C. de F.; DEDIEU, B. Integrated crop-livestock systems: strategies to achieve synergy between agricultural production and environmental quality. Agriculture, Ecosystems and Environment, v.190, p.4-8, 2014. DOI: 10.1016/j.agee.2013.08.009.

LOPES, A.A. de C.; SOUSA, D.M.G. de; CHAER, G.M.; REIS JUNIOR, F.B. dos; GOEDERT, W.J.; MENDES, I. de C. Interpretation of microbial soil indicators as a function of crop yield and organic carbon. Soil Science Society of American Journal, v.77, p.461-472, 2013. DOI: 10.2136/sssaj2012.0191.

LOPES, M.M.; SALVIANO, A.A.C.; ARAUJO, A.S.F.; NUNES, L.A.P.L.; OLIVEIRA, M.E. Changes in soil microbial biomass and activity in different Brazilian pastures. Journal of Agricultural Research, v.4, p.1253-1259, 2010. DOI: 10.5424/sjar/20100841411.

ROS, G.H.; HANEGRAAF, M.C.; HOFFLAND, E.; RIEMSDIJK, W.H. van. Predicting soil $\mathrm{N}$ mineralization: relevance of organic matter fractions and soil properties. Soil Biology and Biochemistry, v.43, p.1714-1722, 2011. DOI: 10.1016/j.soilbio.2011.04.017.

SANO, E.E.; ROSA, R.; BRITO, J.L.; FERREIRA, L.G. Land cover mapping of the tropical savanna region in Brazil. Environmental Monitoring Assessment, v.166, p.113-124, 2010. DOI: 10.1007/ s10661-009-0988-4.

SARAIVA, F.M.; DUBEUX JUNIOR, J.C.B.; LIRA, M.A.; MELLO, A.C.L.; SANTOS, M.V.F.; CABRAL, F.A.; TEIXEIRA, V.I. Root development and soil carbon stocks of tropical pastures managed under different grazing intensities. Tropical Grasslands - Forrajes Tropicales, v.2, p.254-261, 2014.

SERRA, D.D. Avaliação da disponibilidade de nitrogênio para o milho (Zea mays) em solo do Distrito Federal. 2006. 90p. Tese (Mestrado) - Universidade de Brasília, Brasília.

SILVA, V.R.; REINERT, D.J.; REICHERT, J.M. Densidade do solo, atributos químicos e sistema radicular do milho afetados pelo pastejo e manejo do solo. Revista Brasileira de Ciência do Solo, v.24, p.191-199, 2000. DOI: 10.1590/S0100-06832000000100021.

SUBBARAO, G.V.; ISHIKAWA, T.; ITO, O.; NAKAHARA, K.; WANG, H.Y.; BERRY, W.L. A bioluminescence assay to detect nitrification inhibitors released from plant roots: a case study with Brachiaria humidicola. Plant and Soil, v.288, p.101-112, 2006. DOI: 10.1007/s11104-006-9094-3.

VANCE, E.D.; BROOKES, P.C.; JENKINSON, D.S. An extraction method for measuring soil microbial biomass C. Soil Biology and Biochemistry, v.19, p.703-707, 1987. DOI: 10.1016/00380717(87)90052-6.

WALKLEY, A.; BLACK, I.A. An examination of the Degtjareff method for determining soil organic matter and proposed modification of the chronic titration method. Soil Science, v.37, p.29-38, 1934. DOI: 10.1097/00010694-193401000-00003.

WARDLE, D.A. Metodologia para a quantificação da biomassa microbiana do solo. In: HUNGRIA, M.; ARAÚJO, R.S. Manual de métodos empregados em estudos de microbiologia agrícola. Brasília: Embrapa-SPI, 1994. p.419-431.

XAVIER, F.A. da S.; MAIA, S.M.F.; OLIVEIRA, T.S. de; MENDONÇA, E. de S. Biomassa microbiana e matéria orgânica leve em solos sob sistemas agrícolas orgânico e convencional na Chapada da Ibiapaba - CE. Revista Brasileira de Ciência do Solo, v.30, p.247-258, 2006. DOI: 10.1590/S0100-06832006000200006.

YAGY, R.; FERREIRA, M.E.; CRUZ, M.C.P. da; BARBOSA, J.C. Mineralização potencial e líquida de nitrogênio em solos. Revista Brasileira de Ciência do Solo, v.33, p.385-394, 2009. DOI: 10.1590/S0100-06832009000200016.

Received on August 31, 2015 and accepted on February 3, 2016 